\title{
Transformation of Writing Habit on Students at Junior High School and Vocational High School Awal Karya Pembangunan Lubuk Pakam
}

\author{
Dian Marisha Putri, Liza Amalia Putri, Rahmadsyah Rangkuti \\ University of Sumatera Utara (USU), Medan, Indonesia \\ caca_milano@yahoo.com
}

\begin{abstract}
Writing Learning must still be based on Core Competencies (KI) which are then announced in Basic Competencies (KD) and Indicators through learning material. Similarly, the writing material results from field observations and observations. Add another competition for scientific publication of adolescents conducted at the District / City, Provincial and National Level. While the material can be achieved and competitions can be followed. In this paper, it is discussed giving habit transformation of writing through concepts and for example making students see general writing, then students look for references and field data. Only to discuss the substance of scientific writing needs field reinforcement data carried out by students and must be guided directly by the guidance teacher through habit transformation of writing so that the validity and writing of scientific writings can be accounted for. The results of habit transformation in adolescent students are quite significant, so that the 5 texts that have begun to be seen develop and several texts in the process of improvement. Of the seven texts prepared the results are quite encouraging. 2 manuscripts have started the results of their writings by fulfilling the rule of writing.
\end{abstract}

Keywords : transformation; writing habit; students; junior high school; vocational high school; Awal Karya Pembangunan;

\section{Introduction}

Writing is a skill that does not come naturally, unless it is learned and trained. Moreover, writing writing, must have knowledge regarding the contents of essays, procedures that must be passed, designing writing, processing data, writing techniques and writing writing reports. So that all these components complement each other, so that a writing that we want is created. In addition, language supporting factors such as punctuation, capital letter writing, diction, paragraph development in accordance with the theme, title, developing substance, and supporting data are discussed according to the demands of scientific writing. Therefore, if all the expected abilities can be possessed by students, only face-to-face hours are only 3 x 45 minutes per week, this will not be possible, it is in line with what Leonhardt (2002: 21) said, if only relying on writing activities in school it is almost impossible for them to get a sense of language, fresh outlook, and a personal style that can characterize their work.

So it takes a creative teacher who volunteered to try out various teaching techniques, tested methods, and various assignments, so that these problems can be overcome because most teachers in schools teach students according to mandatory hours only, without ever reaching the competency demands of Core Competencies ( KI) and Basic Competence (KD) in the 2013 Curriculum. So that competition for scientific writing competition has never been followed. This is due to the teacher's attention being taken up with various preparations before teaching, so the teacher's attention to writing material for teenagers is neglected. Teachers need a transformation of writing culture, knowledge, and writing competition experience. With this consideration added if the teacher is reluctant to give attention and 
guidance about the writing. To answer these problems, the author tries to make an effort to transform the culture of writing in the hope that unanswered writing problems can be overcome.

\section{Review of Literature}

The ability to write as a skill that is very important in life. By writing we communicate indirectly, but we can master the ideas conveyed through language. In line with that Rusyana (2014: 19) states, writing skills include a variety of abilities to master the ideas expressed, the ability to use elements of language, the ability to use style and ability spelling and punctuation. So, writing skills cover a variety of abilities. What is learned, observed is written in the form of writing, as well as writing script because writing lasts longer than the memory as well as writing which from time to time continues to get revised for the conformity of the writing.

Scientific works in the opinion of Saudah (2010: 1) are written works or other forms that have been recognized in the fields of science, technology or written art or worked in accordance with scientific procedures and following scientific guidelines or conventions that have been agreed or established. Adolescent scientific work must be supported by data obtained in the field, because the data constituting the conditions that become the requirements of a scientific work. The characteristics of the text are: objective, polite and humble, clear, firm, concise, simple and thorough, complex, continuous, and smooth, this is in accordance with Asyari's opinion (2014: 23) scientific essays must pay attention to the conditions namely objective, polite and humble, honest, clear, firm, concise, simple and thorough, complex, continuous, and smooth. Whereas according to Anwar in Asyari (2014: 24) scientific writing should be short, solid, simple, smooth, straightforward, clear, and interesting. A teacher must understand the preparation in scientific writing to produce good scientific work according to Amri (2015: 107) the most basic preparation so that the writing can be developed well namely: preparing themes, topics, writing titles, types of writing, writing functions, defining the writing framework. So, writing ten scientific writing must be honest in mentioning references to material or thoughts taken from other sources, because scientific writing must understand scientific norms or codes of ethics.

Habit transformation as a form of transferring positive habits in order to be integrated into the ethnicity of the community that wants to be infiltrated, to behave, patterned thinking includes knowledge, beliefs, art, morals, laws, customs and traditions as it is advocated. This is according to Kroeber and Kluckhon in Bakker (1984: 15-19) showing the definition of culture consists of various patterns, behaving well, thoughts, feelings and reactions obtained and mainly derived by the symbols that compile their achievement separately from groups humans, including the manifestation of material things. The center of the essence of culture consists of traditions of aspiration or merit and especially attachments to values. The values that want to be transformed are creative culture in writing works for teenagers. The transformation of the creative culture is carried out by the teacher as the teacher teaching the theory of writing to students, so that they understand the steps that must be followed when conducting scientific writing in adolescents.

So, habit transformation with tutorial or tutoring is a technical term of learning that is defined as guidance and learning assistance. According to the Ministry of Education and Culture (2005: 1090) the tutorial is class coaching by a teacher (tutor) for a student or small 
group of students. So, habit transformation is a procedural framework of learning that focuses on providing guidance and learning assistance by the teacher (teacher). Guidance with assistance aims to make students clash with one learning material that requires intensive learning guidance and assistance, so that the competencies to be achieved can be fulfilled according to demands.

\section{Result}

This writing is a tutorial approach in accordance with the desired results. The location of the activity was carried out in Awal Karya Pembangunan Lubuk Pakam School on junior and vocational high school students. a) Share a group of young scientific researchers consisting of 4 or 5 people per group. b) Editing the titles of adolescent scientific writing in each group. c) Guiding and helping students understand the concepts of adolescent scientific writing in general and providing examples. d) Guiding and helping each group in preparing reference materials (the theoretical foundation of the library and the internet) and improving the technical writing. e) Helping, guiding and giving instructions to each group about supporting data that will strengthen writing, and the validity of writing. f) Guiding and helping each group to analyze data and discuss the collected data. g) Guiding and helping each group make their own writing conclusions and suggestions to those related according to the discussion of writing. h) Assist and revise each group work, in compiling bibliography, introductory words, authorization sheets, table lists, table of contents, and attachments. i) Each group revises all errors and shortcomings in the adolescent scientific writing report.

\section{Discussion}

The results of analyzing the data needed in this writing are used notes in analyzing the progress of this writing used tools such as consultation books / writing guidance books, and data collection tools in the form of: a) Implementing the tutorial system approach (guided) and observing the habit transformation of writing. b) Comparing the increase in writing during the writing c) Gathering the findings of students and the obstacles faced when in the field. Before carrying out the writing, first an initial test of the ability of students is carried out in order to find out the basic abilities of students in mastering the basic concepts of writing teen scientific papers. From the initial test conducted, the results were $35.15 \%$.

Based on the guidance and observations made by the teacher, the actions taken by the teacher are as follows: a) The teacher divides students into ten groups consisting of 4 or 5 people per group. b) The teacher edits the titles given by each adolescent scientific writing group. d) In initial learning, the teacher presents the concepts of writing and examples of writing. e) The teacher assigns an assignment to each person to prepare reference materials (for the theoretical basis of the library and the internet) that are in accordance with the title of each group then write according to the conceptual framework.

The teacher corrects and guides student writing that is not in accordance with the concepts being taught, and explains the mistakes again so that they do not occur in other groups. For each student's scientific writing report, it is used as a group report, then the group report is duplicated and submitted to another group, so that everyone can correct errors that exist in each group in the form of discussion, guided and guided by the teacher: footnotes and 
quotes. b) The teacher gives assignments to each group to collect supporting data on the field that strengthens the evidence so that the validity of writing is more accurate. c) The teacher guides and analyzes the data of each group collected, then each group analyzes each data and discusses the lack of data collected, and completes it. d) Each group presents constraints while taking data in the field, the guiding teacher provides solutions to every problem in the field.

Furthermore, the results of the writing show: a) Students are very enthusiastic in completing the report on scientific youth writing, according to the group. b) Students have understood the writing technique. c) Students have been able to write writing reports in accordance with library studies. d) Several groups have been able to report field data, and results of group experiments. e) Some groups have been able to make conclusions and suggestions. f) Several groups have been able to compile bibliography, footnotes, and quotes in. g) Smart students are able to work with their groups. h) Students who have less ability, collected in one group, start working with students who want to do it. i) Students who still have difficulty understanding the concept, are given remedial and who have understood are given enrichment.

Based on the results of habit transformation in guidance with a tutorial approach to students in the class in the form of adolescent scientific writing groups. Then the results obtained include: a) groups that have not written their writing report due to several factors. b) Groups that have completed the results of their group work have increased, namely 6 groups. c) Two groups live in completing the report from the collected data. d) One group that changes the title, must start from the bottom, so that the report has not been completed. e) One group that has less ability in class still has problems in compiling reports.

Based on the data collected from each of the mistakes made by students, it can be seen that the causes of students do not write are: a) The teacher does not want to teach the concepts of youth scientific writing. b) Conceptually students do not understand the concepts and techniques of adolescent scientific writing. c) Even if there is a paper making assignment, it is only given a theme or title to students, both individuals and groups, without ever being conceptually taught or practiced. d) After the paper or student's scientific work has been completed, the teacher does not even tell the location of the mistakes made by the students not even correct them at all. e) The teacher does not want to guide or not correct the work of students because it takes time, while the preparation of teaching and others need attention, so that students have never done the activity of writing scientific papers. f) Teachers are reluctant to motivate students, so that they are enthusiastic about writing teen scientific writing. g) Cases found that there is still a lack of capacity of groups, and groups that have no cooperation. Likewise, the title must be replaced because there is no writing support equipment.

Continued habit transformation was carried out with results: students' enthusiasm that was seen from the meeting times still seemed to develop, the desire to complete the adolescent scientific writing report so that the following results were obtained: a) Groups were able to report field data, and experimental results done reinforcing writing. b) Several groups have been able to draw conclusions and suggestions, bibliography, footnotes and references. c) Constraints faced in the field when taking data, observations, interviews and distributing questionnaires to respondents can be overcome. d) Group work already has good cooperation and is aware of the lack of cohesion, during the conduct of youth scientific 
writing. f) Group work activities begin to live, so that the results of work when collected are already there. g) Group competition is evident, due to persistence, and the tenacity of group members to complete their writing reports. h) Students are able to write adolescent scientific writing reports in the form of group writing reports. i) Groups have been able to report field data, and the results of experiments conducted reinforce writing. j) Several groups have been able to draw conclusions and suggestions, bibliography, footnotes and references. $\mathrm{k}$ ) constraints faced in the field when taking data, observations, interviews and distributing questionnaires to respondents can be overcome. 1) Of the ten groups that carry out juvenile scientific writing, all the writing reports have been completed, but 2 groups still need further guidance.

The results obtained are: a) Students are very enthusiastic in completing a report on scientific youth writing according to their group. b) Students already understand the technical writing. c) Students have been able to write adolescent scientific writing reports in accordance with library studies. d) Five groups can already report the field data, and the results of group experiments. e) Five groups can make conclusions and suggestions. f) Six groups have been able to compile bibliography, footnotes, and quotes in. g) smart students are able to work with their groups. h) Students who have less ability, collected in one group, start working with students who want to do it. i) Students who still have difficulty understanding the concept, are given remedial and who have been able to be enriched. $\mathrm{j}$ ) group work already has good cooperation and is aware of the lack of cohesion, during the conduct of youth scientific writing. k) Group work activities begin to live, so that the results of work when collected are already there. 1) Group competition is evident, because of perseverance, and the tenacity of group members to complete their writing reports.

\section{Conclusion}

The habit transformation of creativity carried out by the teacher can be concluded: a) The group work has good cooperation, because the disharmony of the group will still harm their respective groups. b) Group activities begin to live so that the results of group work when collected are already written reports. c) Group competition is evident and persistence, tenacity, groups compete in completing their writing. d) Five scientific writing texts have had significant results. e) Students are able to write scientific writing reports in the form of group writing reports. f) Each group can report field data, and experimental results that strengthen writing. g) Constraints faced by students when in the field to collect data, observation, interviews, and distributing questionnaires to respondents can be overcome. $h$ ) five groups that conduct scientific writing, the result is that all groups have completed the writing report. But two groups still need guidance.

The suggestions are as follows: a) Every teacher, especially Indonesian Language teachers should understand and master the technicalities of adolescent scientific writing, so that teaching materials can be implemented in the form of writing. b) Teachers in general must teach technical knowledge writing to students. c) After conceptual teaching to students, then work together with other teachers to provide the task of educating students in the class. d) Teachers should continue to provide guidance, direction, guidance and learning motivation to students so that revisions are carried out continuously so that scientific work is feasible and good. 


\section{References}

Amri, Yusni Khairul, 2015. Bahasa Indonesia: Pemahaman Dasar-dasar Bahasa Indonesia. Atap Buku: Yogyakarta.

Asyari, S.Imam, 2014, Petunjuk Teknis Menulis Naskah Ilmiah. Surabaya: Usaha Nasional. Bakker. 1984. Filsafat Kebudayaan: Sebuah Pengantar. Yogyakarta-Jakarta: Penerbit Kanisius dan BPK Gunung Mulia.

Hamalik ,Oemar, 2015, Metode Belajar dan Kesulitan Belajar. Bandung: Tarsito.

Leonhardt, Mary, 2012. 99 Cara Menjadikan Anak Anda Bergairah Menulis. Bandung: Kaifa.

Rusyana Yus, 1984, Bahasa dan Sastra dalam Gamit Pendidik, Bandung.: Diponegoro. Saudah, Ali dkk, 2010, Pedoman Penulisan Karya Ilmiah. Malang : Universitas Malang. 